\title{
Approaches to identification and interpretation of mining heritage: the case of the Jáchymovsko area, Ore Mountains, Czechia
}

\author{
JAKUB JELEN ${ }^{1}$ and ZDENĚK KUČERA ${ }^{1}$
}

\begin{abstract}
Mining heritage refers to a complex of both tangible and intangible features and values whose formation was associated with the development of mining activities in the given region. After mining activities are completed, original industrial and related subsidiary structures either fall into dereliction or are subject to conversion. One of frequent modes of transformation of objects is their presentation as heritage and utilization for the needs of tourism. The way of its interpretation and presentation to the public plays a very important role in mining heritage preservation, since it may be attributed not only historical and architectural values, but may also reflect political or ideological background of the period in which it was formed. The paper discusses the definition of mining heritage and the questions concerning its origin, recognition, protection, management and interpretation in the case of the Jáchymovsko area, part of the cross-border mountainous region in Czech-German borderland which is being proposed to be included into the UNESCO heritage list. The Jáchymovsko area is distinguished by the fact that it combines a 500-year-old history of mineral extraction and therefore local mining heritage is very diverse. Thus, different types of local mining heritage and its conversion for other purposes (e.g., tourism) are analysed, ways of local mining heritage identification, management and interpretation are discussed.
\end{abstract}

Keywords: mining heritage, interpretation, Jáchymov, Ore Mountains, Czechia

\section{Introduction}

Extraction of minerals is one of the oldest human activities. Mining ranks among the most important industrial sectors, as it supplies raw materials to a large number of other industries. Like every human activity, the purpose and technique of mineral extraction develops through time. This includes discoveries of new resources, expansion of knowledge in the industry, invention of new procedures and techniques, and closure of operations after deposits of the particular resource are exhausted (KAFKA, J. 2003). The process of minerals extraction contributes to formation of extensive complexes of cultural landscape features and a landscape that is heavily transformed by human activities
(Csorba, P. and Szabó, S. 2009), the mining landscape (BRIDGE, G. 2004). The extraction of mineral resources at a particular location is also associated with particular style of life, and with the creation of a specific social and cultural environment (Cole, D. 2004; CouPland, B. and Coupland, N. 2014). After mining activities are terminated, a question arises as to how to treat the remaining complex of individual features and phenomena (Conesa, H.M. et al. 2008).

The extractive industry is still considered an important sector, but the material remnants of mining activities (headframes, spoil heaps, mine dumps, etc.) have been regarded for a long time as unsightly landscape features, and there were efforts in the past to obliterate the traces of modern min-

\footnotetext{
${ }^{1}$ Should be in reverse order: Charles University, Faculty of Science, Department of Social Geography and Regional Development, The Research Centre for Cultural and Historical Geography. Albertov 6, 12843 Prague 2, Czechia. E-mails: jakub.jelen@natur.cuni.cz, zdenek.kucera@natur.cuni.cz
} 
ing (Fragner, B. and Zikmund, J. 2009). With respect to treating these remnants as features suitable for preservation and deserving to be protected as heritage, there still appear conflicts, which can have the form of ideological disagreements (decision-making on whether these remnants should be protected or not), or objective obstacles associated with a change of function, such as environmental pollution during mining or the size of the areas affected by mining. Another factor may be the low attractiveness of mining features stemming from a different standard of beauty (Conesa, H.M. et al. 2008).

In recent decades, however, there has been a shift in the perception of these complexes and they are now perceived as heritage that should be protected and interpreted to the public, since it contains values proving (not only) the level of advancement and technical skills of the predecessors (Toмíškoví, M. 2013). Among the most prominent examples of these activities is the emergence of the field of industrial archaeology in the UK in the 1950s, the organisation of international conferences devoted to the topic of industrial heritage (the first one took place in Ironbridge, Great Britain, in 1973), and the establishment of the International Committee for the Conservation of the Industrial Heritage - TICCIH (BLAžKové, T. and MatoušEK, V. 2013).

The aim of this paper is to discuss the definition of mining heritage and questions concerning its identification and interpretation, using the example of the Jáchymovsko area. This area is characterised mainly by a long history of mining, an extraordinary diversity of the mineral resources mined, and large quantities of mining relics. Since 2009 is local mining cultural landscape being considered as part of the nomination of the Krušnohoří (Ore Mountains) cross-border mining area to the UNESCO list (URBAN, M. et al. 2011). The complex of mining related landscape and cultural features present in the Ore Mountains constitutes a unique example of a mining heritage complex in global context. Mining heritage of the Jáchymovsko area started to be first recognized by the Czech government already in the second half of the $20^{\text {th }}$ century (the establishment of the Royal Mint museum in 1964). However, most of the interest in this heritage has been growing only recently with the more active involvement of public in its protection, as museums are being established by various local stakeholders (municipalities, civic associations, individuals, etc.) and miners' associations are being founded.

The example of the Jáchymovsko area enables the discussion on the content of the complex of mining heritage and the significance of its individual features. Knowing the processes, values and stakeholders involved in recognition, management and interpretation of the mining heritage serves for better understanding and learning of its nature and the ways and options of its protection and presentation.

Last but not least, this paper also aims to highlight the uniqueness of the Jáchymovsko heritage and contributes to its promotion and preservation by analysing its formation and ways of interpretation.

\section{Significance of heritage}

What is meant by heritage?

Heritage is associated with many different meanings. Its legal interpretation dates as far back as the $14^{\text {th }}$ century, when it meant passing down tangible assets from one generation to the next. Heritage therefore entailed remnants of the past passed down to a future owner (VANĚČEK, V. 1933). This meaning of the word has been preserved until today. Heritage as a legal notion is defined by laws (in the Czech Republic it is Act No. 89/2012 Coll., the Civil Code) as the right to inheritance, i.e. the right to the property of the deceased. But heritage is also a subject of many other fields of study, such as heritage conservation, historiography, culturology, tourism, and/or heritage studies as a separate discipline. 
All these disciplines are concerned with heritage formation, management and interpretation. In this respect, heritage is no longer purely the notion defined in legal terms, even though this common base can be found in all of its other concepts. Heritage can be viewed as a complex of elements and phenomena formed by cultural memory and people's perception of the past in a particular context. It refers to significant objects, people, places, events, opinions or relations in the cultural environment of a particular time, both in material and non-material terms (Holtorf, C. 2002). It means the relics of the past that are used actively for various purposes at present (SMITH, L. 2006; HaRveY, D.C. 2008). Heritage therefore represents a set of internal values and meanings related to the past (URRY, J. 1990), which are also interpreted and presented externally (HARVEY, D.C. 2001).

In the broadest sense of the word, basically anything that people choose to protect can be regarded as heritage (HEwison, R. 1989; HowARD, P. 2003). It can therefore be understood in very different and subjective ways (Ashworth, G.J. and Tunbridge, J.E. 1996; Graham, B. et al. 2000; Harvey, D.C. 2001). Deciding what is considered heritage and what specific values should be attached to it is up to each individual as well as the whole of society. Heritage supports the importance of a place and the sense of belonging to a particular community (SмITH, L. 2006).

In order to be identified and categorized, heritage is defined in legal documents. At international level, such legal documents include the Convention concerning the Protection of the World Cultural and Natural Heritage (Národní památkový ústav 2006). The Convention divides heritage into three types: natural, cultural, and combined. The definition of heritage in the Convention is based on the fact that it contains outstanding universal features from the point of view of history, art or science (cultural heritage), of science or conservation of nature or natural beauty (natural heritage) or at least part of the both aspects (combined heritage).
Cultural and natural heritage differ mainly in their nature, i.e. the fact that natural heritage is not primarily a product of cultural activities within society. Cultural heritage, on the other hand, serves to represent human genius. Although often perceived as distinctive, these two groups are very often interconnected (LowenthaL, D. 2005).

When handling heritage, it is always important to identify its specific values and to define its accompanying characteristics, such as utility and functional properties, the procedure used in its production or its use, and/ or aids and accessories (KeSNER, L. et al. 2008). Heritage can be classified in many ways according to various criteria. HowARD, P. (2003), for instance, distinguishes seven categories of heritage (nature, landscape, monuments, sites, artefacts, activities, and people). KučERA, Z. (2009), on the other hand, classifies heritage according to its origin (ours vs somebody else's), nature (tangible vs intangible), significance (local, regional, transnational or global), ownership (personal vs collective), preferences (positive vs negative), and duration (old vs new). Mazáč, J. (2003) classifies heritage by fields of human activity (transport, spas, metallurgy, glassmaking, etc.).

\section{How is heritage created?}

To answer the question of how heritage is created, it is necessary to explain why and by whom it is created (Harvey, D.C. 2008). Heritage needs to be understood as a subjective product of processing the past at present (Lowenthal, D. 1985; Ashworth, G.J. and Tunbridge, J.E. 1996; Lowenthal, D. 1998). Heritage does not arise or exist by itself. It is influenced and determined by external factors and conditions. Some features may already be created with the intention to serve as cultural heritage, with the aim to refer to and commemorate important events or persons. The values with which the particular heritage asset (e.g., memorial, monument) will be associated are specified during its very creation. Such heritage usually con- 
tinues to be treated in line with its original purpose throughout the course of its existence. Unless society undergoes any political or ideological transformations or unless any natural disasters occur, such heritage is relatively stable and fulfils its function continuously.

On the other hand, there is also heritage that was formed through transformation or termination of the original function of the objects. Such objects have become the subject of protection and have been given a new purpose (RIEGL, A. 2003). This is what has been termed as "the second life as heritage" (Coupland, B. and Coupland, N. 2014). Values are assigned to such heritage on the basis of its analysis in the course of its existence after the change of function. Figure 1 shows features that were created primarily as heritage ( $1^{\text {st }}$ column $)$ as well as features that turned into heritage secondarily $\left(2^{\text {nd }} \mathrm{col}-\right.$ umn). The last column shows new functions acquired by the feature after it has become viewed as heritage.

In the process of creating heritage through transformation of the original function, and in handling such heritage in general, an important role is played by the time aspect, which means by how long ago the original purpose of the objects protected today was lost or changed. Concerning castles, chateaus or old military fortresses whose original purpose ceased to exist a relatively long time ago, it is much easier to treat them as heritage, since they are supposed to recall a distant and often idealised past that will never repeat and that could not be usually experienced by members of the present generation. A problematic group is constituted by monuments whose original purpose continues to exist in general, but the individual monuments no longer meet this purpose. These are a typical example of industrial and thus also mining heritage.

Whether heritage is created directly or through conversion, its recognition depends mainly on the assignment of specific values to a particular feature and on the effort to maintain these values (Hewison, R. 1989; HowArD, P. 2003). The identification of these values forms a basis on which the management of the heritage will depend, determining how the heritage will be handled and what purpose it will fulfil.

\section{Emergence of mining heritage}

Industry as a whole is still an active and very important sector of the economy that has an

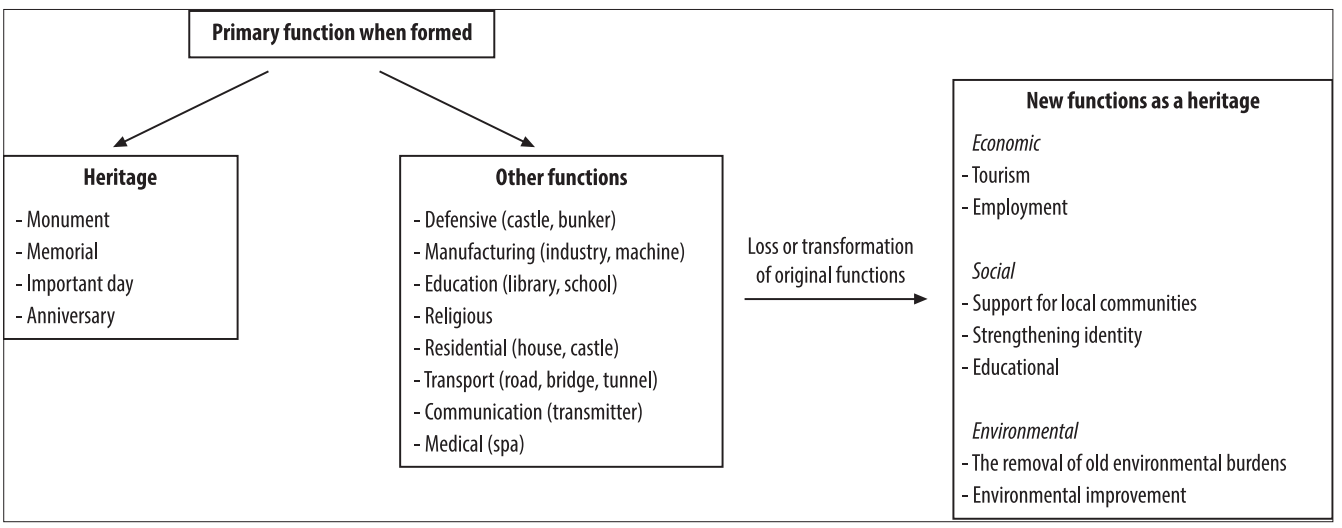

Fig. 1. Scheme of heritage formation and transformation of its functions. Source: Adapted from MAZÁč, J. (2003) and Cole, D. (2004). 
undeniable significance for the entire society, whether in terms of employment or in terms of GDP creation, among other things (KopačKA, L. 1996). However, as a consequence of wider societal and economic transformations in the post-industrial era, its individual elements (plants, premises, etc.) cease to fulfil their original purpose and gain new functions (EdENSOR, T. 2005; KIss, É. 2009). Since industry has significantly influenced character of societies in developed countries, it has become also an important part of their cultural identities. Thus, it is very important to preserve the quickly vanishing legacy of industrial activities by protecting its remnants (Loures, L. 2008). At the same time, many debates are emerging revolving around the issue of identifying and determining which remnants will be conserved, protected and designated as heritage and, last but not least, how they will be treated and what new purpose they will serve (LeDNICKÝ, V. 2004; Marhounová, M. 2009). According to some, industrial heritage embraces objects objects or complexes of objects created in the course of the industrial revolution and the intensive development of industry over the past 200 years (Hudson, K. 1965). Such an approach could not, however, be applied to a wide range of industrial monuments both in Czechia and in the world, since many of them are considerably older.

Typical examples of these may include the $16^{\text {th }}$ century mining monuments found on the territory of Czechia, for example in the Ore Mountains (Urban, M. et al. 2011). According to other approaches, objects dating from any period of evolution of human society can be considered industrial heritage (RAISTRICK, A. 1972). These concepts deal with the given topic much more accurately, but it is not possible to think about industry as it is known today in reference to the times before the period of industrial revolution. As a general principle, the creation of industrial heritage is associated with a loss of productive function of the affected operations, which is substituted by efforts to find a new use for the remaining objects and sites (KolejKA, J. and KLimáneK, M. 2012).
In the context of the characteristics presented above, mining heritage means for the purpose of this paper a set of tangible and intangible features as well as with them associated values and meanings (historical, social, cultural) referring to mining and miners. These features and values associated with them are actively recognized, managed, interpreted and presented to the public and passed on to future generations by various stakeholders operating on different levels (from local to global). Mining heritage, which refers to the extraction of minerals and cultural activities connected with it, forms a specific subgroup of industrial heritage (MAzÁč, J. 2003; Loures, L. 2008). What makes it relevant is mainly the fact that almost no industrial production would do without mining. Mining is therefore at the beginning of the entire process of industrial production.

Mining heritage may involve either tangible (mines, buildings, machinery, miners' uniforms, etc.) or intangible (techniques, production procedures, miners' customs and traditions, etc.) remnants. Complexes of such heritage form extensive mining landscapes. Transformation of the original function of mining areas, connected with search for their new utilisation, can be observed in Europe since the 1970s (KolejKA, J. 2014). This does not mean that the mining industry no longer plays a significant role, but its structure, impacts and spatial layout are different. Since a specific social and cultural environment evolves in the area where mining is developed for a long time, the changes connected with deindustrialization subsequently lead to a demise of the specific mining community (Coupland, B. and Coupland, N. 2014). Underground work, extremely challenging and dangerous, provides jobs to a large number of people and is linked with a wide range of other activities. After its termination, these accompanying processes are interrupted as well. Consequently, if there is effort to preserve mining heritage as a complex, it should not be aimed at saving just the buildings of mines and operations themselves but also at maintaining the intangible heritage (WHEELER, R. 2014). 
Mining heritage is defined by those who want to use, preserve or protect the remnants of mining activities and related processes, since these refer to specific cultural values. This is why they are trying to find a new use for the preserved remnants of former mining activities while recalling their past and interpreting and presenting it to the public. The process of heritage formation includes among other things identification and recognition of remnants of mining as heritage.

There are many ways of using the mining heritage, most of them depending on the stakeholders' motivations. The objects are used in various ways (e.g., for the needs of tourism, for conversion to dwellings or for commercial purposes; sometimes activities connected with former purpose of the objects are also present: pumping water, warehouses, repositories, etc.). When using these objects, it is important to respect not only the principles of heritage protection and conservation, but also the sustainability and significance of the particular heritage in economic, social as well as environmental terms. Such sustainability cannot be achieved fully in all aspects, but it is necessary to find the greatest possible concordance in fulfilling the purpose for which the particular heritage was created or transformed (CoLE, D. 2004). At the same time, no significant losses in the represented values and authenticity should occur, such as a loss of the architectonic value due to excessive renovations (MARHounová, M. 2009). Transformation of mining industry from mining to other functions is also associated with societal changes. For example, after the mines are closed, there is an increase in unemployment, which can't be replaced by newly created jobs (e.g., in tourism).

\section{Usage of mining heritage and the process of its interpretation}

Mining heritage is handled by a large number of individuals as well as institutions. In terms of categorisation it is possible to distinguish three basic groups of stakeholders: the public sector, the private sector and the interest sector. Each of these groups pursues its own primary goals, and the ways of their functioning result from the purposes for which they use the particular heritage. Figure 2 shows an overview of the players handling the mining heritage, examples of the heritage they use and their primary and secondary goals in handling it.

There are notable differences among the primary goals, as a consequence of which each particular heritage asset is treated differently. The main goal of all interest groups should be not only to preserve the mining heritage but also to make it accessible and provide its interpretation to the public, since this is the way of passing it down to future generations (KESNER, L. et al. 2008). For private entities, in particular, the interpretation and presentation of mining heritage is often of secondary importance, especially when a commercial use of the particular heritage asset is in conflict with the demand of accessibility (e.g., for safety or capacity reasons). Individual stakeholders also use different methods of interpreting the heritage to the public.

Interpretation is a creative activity connecting a particular site with visitors and

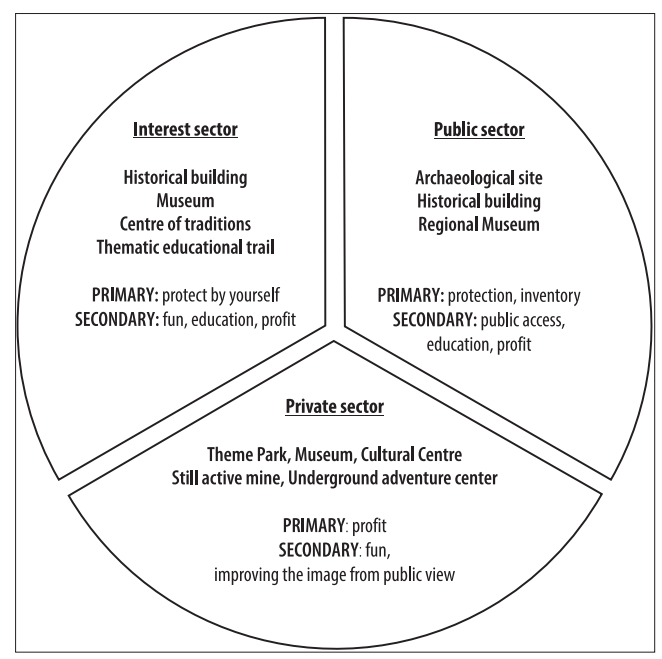

Fig. 2. Stakeholders dealing with heritage, examples of heritage they hold and of their aims. (Compiled by the authors) 
bringing them not only an educational but also an emotional and spiritual experience (Nuryanti, W. 2005; Ham, H.S. and Weiler, B. 2012). Interpretation aims at preservation and presentation of particular values recognized by heritage management as significant, with the goal of making the visitors reflect on the facts and meanings presented to them. A successful process of interpretation leads to an increase in interest and respect for the particular heritage asset (KESNER, L. et al. 2008). The interpretation of a particular heritage site creates a specific opinion on it and on the values and past it represents, so getting acquainted with the heritage does not depend merely on what but mainly how and by whom it is interpreted (AsHwORTH, G.J. and Tunbridge, J.E. 1996; Sмітн, L. 2006). Interpretation can be conducted in many ways, from a simple text description to getting visitors involved by means of interactive exhibits (РТÁčEK, L. 2004). A basic overview of methods of interpretation is shown in Figure 3.

Selecting a higher level of interpretation will increase the probability of achieving its goals. Which is why it is advisable to select tools from the upper "levels" of the pyramid. To create a

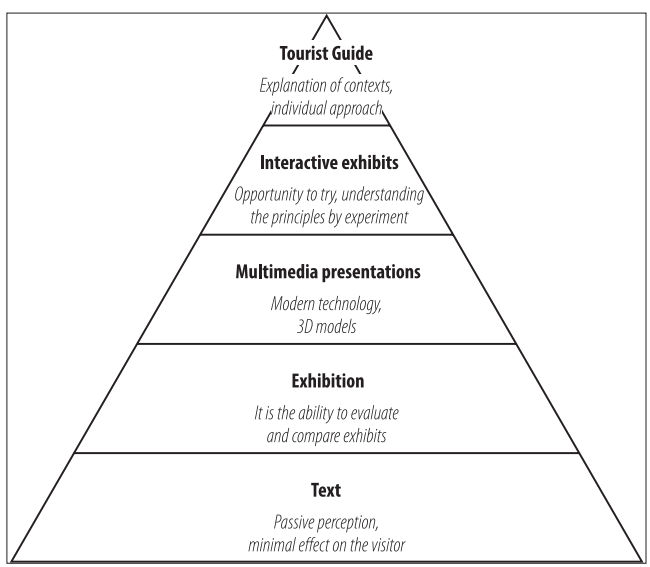

Fig. 3. Pyramid of interpretational instruments. Note: The higher the level selected, the greater the chances of remembering the topic by observers and of meeting the objectives of interpretation. Source: Adapted from KESNER, L. et. al. (2008) comprehensive picture of the facts presented, the best method is to combine several interpretation tools, for example to accompany exhibits with a text while adding interactive features to the exhibition at the same time. A very interesting type of interpretation is provided by witnesses who share their own experiences by telling stories, thus adding an emotional level to it. A special category is formed by organizing various events (music and cultural events, discussions, etc.) that combine several elements, depending on the type of event. However, it should be noted that interpretation is a very complex process. It does not matter only the form of presentation, but also the context. Interpretation is subjective and therefore those who present certain theme can never be completely sure of how the content of the message will be interpreted by visitors.

Mining heritage is frequently utilised for touristic purposes. One of the world's most outstanding examples of the conversion of former industrial and mining area into recreational zone is the Zollverein coal mines complex in Germany, where the former structures were rebuilt, among other things, in tourist attractions. The significance of the mine is also documented by its inclusion on the UNESCO list. Using mining heritage to interpret historical and cultural values through tourism is one of ways of preserving it, since this method increases the overall awareness of the general public about the significance of the heritage encountered. However, to avoid damage or degradation of heritage sites by intensive visitor traffic, planning and professional approach are also important. Various measures are used for this purpose. At underground sites, for instance, the maximum number of visitors is limited. It is very important to take a holistic approach towards interpretation of mining heritage, since it is not just a set of individual elements (WHEELER, R. 2014).

It is necessary to show visitors not only material remnants but also links and processes. This is why the combination of as many interpretation tools as possible is used. For example, on selected mining heritage sites in 
Great Britain former miners are employed as guides. They tell visitors their stories from the time they worked in the mines, which adds an emotional level to the heritage interpretation and, in a way, helps preserve the character of the local mining community (Coupland, B. and Coupland, N. 2014). The main contribution of the use of mining heritage for the needs of tourism consists in its role in improving the image of the particular site, in its overall promotion and in raising public awareness about it. In some cases, tourism can also have a multiplication effect, become a catalyst for other processes and contribute to the development of related activities, such as the organisation of festivals or shows and the establishment of music groups (Cole, D. 2004).

\section{Mining heritage in the Jáchymovsko area}

\section{Protection of mining heritage in Czechia}

On the national level, heritage protection and the implementation of the respective agreements is the responsibility of the individual countries and authorised institutions. Heritage protection in institutionalized forms has a great tradition in Czechia. The first legal documents regulating the protection of cultural monuments was originated in 1749. The first legislative measure for the protection of monuments on the Czech territory (at that time part of Austria-Hungary) is the imperial decision of 1850 about state protection of monuments (RIEGL, A. 2003; ŠTULC, J. 2004). Nowadays is the protection of cultural monuments mainly the task of the Ministry of Culture of the CR and organisations established by the ministry. One of them is the National Heritage Institute (Národní památkový ústav, NPÚ), founded in 2003, which serves as a specialised organisation building on the tradition of previous institutions (ŠTULC, J. 2004). Besides NPÚ, there are many other bodies (the Heritage Conservation Inspection, etc.) as well as independent groups and associations that are actively engaged in heritage protection.
Cultural monuments are defined by Act No. 20/1987 Coll., on National Heritage Conservation. This law governs the designation of assets as heritage, their protection as well as the cancelling of heritage designation, dividing the listed monuments into different categories according to their significance. Unlike the UNESCO Convention, this law does not deal with intangible monuments such as traditions and customs. The intangible heritage is entirely in the care of interest associations, which maintain and develop the traditions. Awareness of the existence of intangible heritage and its institutional framing in applicable legislation are important steps towards its preservation. This issue is also obvious from the example of the mining heritage, where heritage protection on the national level only deals with structures (buildings, mines, etc.) but not with the intangible heritage in the form of customs and traditions (such miners' festivals), which would serve to preserve the specific social and cultural relations and local identities.

According to Kratochvílová, A. (2014), the NPÚ registers more than 200 objects that can be directly identified as evidence of the development of mining activities. These enjoy various degrees of heritage protection. The highest (though not attained as yet) of them is the nomination of the mining cultural landscape of the Ore Mountains region, including the Jáchymovsko area, to the UNESCO list (Urban, M. et al. 2011).

\section{Characteristics of the area}

Jáchymovsko area lies in the Ore Mountains which undoubtedly rank among the most significant mining regions within Czechia. Thanks to their multifarious geological development, Ore Mountains are abundant in many types of metalliferous as well as nonmetalliferous raw materials, which have been extracted here for more than 700 years (Karel, T. and Kratochvílová, A. 2013). This region is known for several centres, the most important of them being the town of 


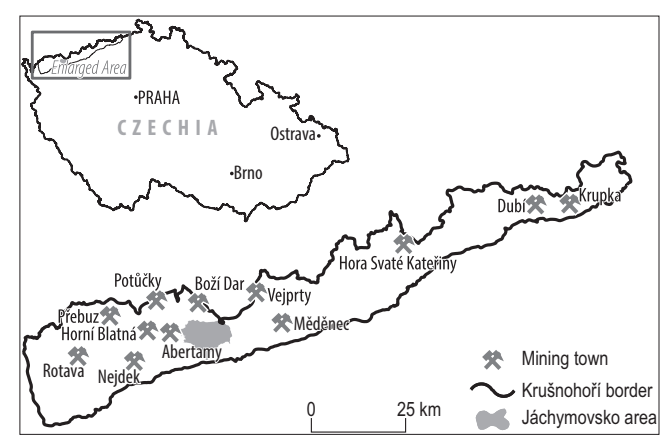

Fig. 4. Location of the Jáchymovsko area in northwest Czechia (edited by the authors).

Jáchymov (2,622 inhabitants in 2016) and its surrounding area. The location of the area is shown in Figure 4.

Jáchymov with its surroundings became famous mainly thanks to the wide range of extracted raw materials in various periods of history. As early as in the $16^{\text {th }}$ century, rich deposits of silver were discovered here. It was the biggest silver deposit of its time in Europe, and a local mint minted silver coins (thalers). Jáchymov was the second largest town in the Kingdom of Bohemia, with intensive construction of mines and residential buildings taking place here. After the silver deposits were exhausted, cobalt, nickel, arsenic and bismuth were extracted here in the $17^{\text {th }}$ and $18^{\text {th }}$ centuries (HLOUŠEK, J. 2016). In the mid- $19^{\text {th }}$ century, uranium ore started to be mined. At the beginning, it was used for the production of paints at a local factory, and later, after the discovery of radium in the early $20^{\text {th }}$ century, it was used for the extraction of this element (SEIDLERová, I. and SEIDler, J. 2007).

From the 1940s to the 1960s, uranium was mined for the needs of the arms industry. Between 1945 and 1963, 29 pits were excavated and more than 1,100 kilometres of horizontal mine workings were dug out. The deposit was explored to the depth of 750 metres, and a total of 7,200 tons of uranium were mined (Pluskal, O. 1998). Since this period saw the highest intensity of mining, the number of miners was also at its peak. The mining also required a huge number of other workers, but despite mass recruitments, there was always scarcity of labour force. Prisoners living in labour camps built near each mine started to be deployed to work in the mines. Prisoners worked in the Jáchymovsko area in the uranium mines between 1945 and 1964 and could be divided into three groups: criminal, retributive, and political (LePKA, F. 2003). In Jáchymov also the oldest therapeutic radon spa in the world, founded in 1906, are located (HLOušEK, J. 2016). The spa is still in operation thanks to the active mine Svornost.

The complex of the mining heritage of the Jáchymov district

A basic and detailed overview of Jáchymov's mining heritage is shown in Table 1. This overview has been drawn up on the basis of an analysis of features that can be considered mining heritage pursuant to its definition, i.e. they are remnants of the past which are actively used for various purposes at present (Smith, L. 2006; Harvey, D.C. 2008) and represent a set of values and meanings related to the past (URRY, J. 1990).

From the viewpoint of selection of the features, neither the degree of state heritage protection, nor the ways of their use are decisive. The important thing is that they refer in some way to the mining past of the place, that they are associated with some kind of interpretation (e.g., a text, exhibition, exposition), and that they are still used in daily practice (for example, for commercial, educational, medical or other purposes).

The mining heritage of the Jáchymovsko area emerged gradually. The first major milestone in its formation can be seen in the foundation of the Royal Mint museum in 1964 which is now managed by the representatives of the Karlovarský kraj region. The largest expansion of interest in Jáchymovsko mining heritage has been taking place since 2000, as miners' associations and music 


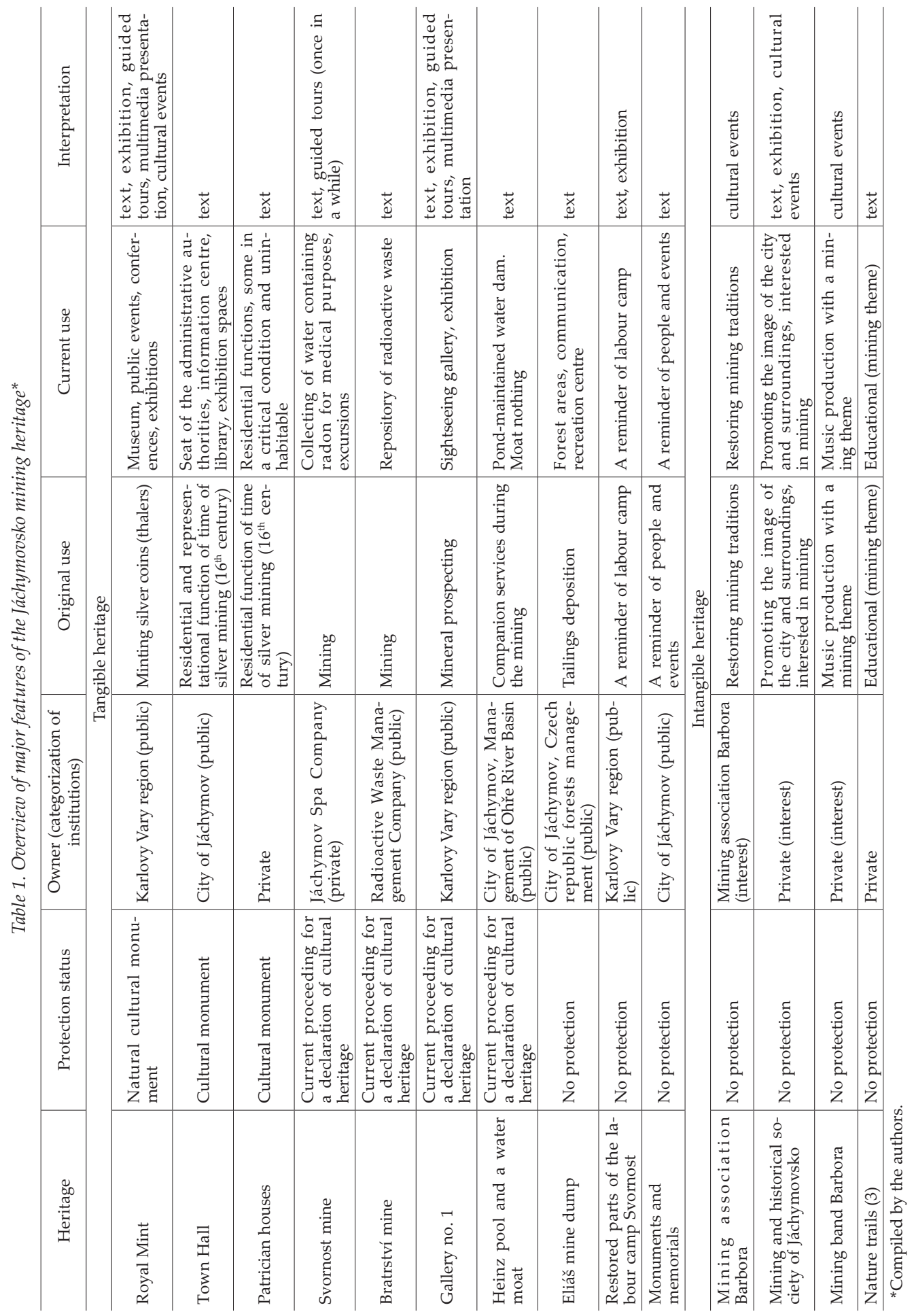


groups are being founded, new museums are being opened and nature trails are being built, among other things. Stakeholders dealing with the interpretation of local mining heritage in Jáchymov are diverse (among them are Karlovarský kraj region, municipality, local citizens, former miners or their descendants, and others). However, one of the most important stakeholders is the Regional museum in Sokolov, which opened the exhibition of Gallery no. 1 in Jáchymov. The only place in Jáchymov, where it is possible for general public to experience the postmontane underground environment directly.

An analysis of the mining heritage shows that the local heritage is both tangible and intangible. It is represented by many features, including immovable objects (buildings), anthropogenic interventions in the landscape (ponds, waterways, spoil heaps, etc.), monuments and memorials as well as celebrations, traditions and nature trails. Local miners' songs and music groups can also be included in the category of intangible heritage. The entire complex of tangible and intangible cultural features forms exceptional identity of the mining area. The mining past is represented not only by remnants of mining but also still active operations, commemorations of traditions and of the miners themselves, not excluding the prisoners who worked in the mines (JELEN, J. and KuČERA, Z. 2017). Their fates are commemorated by preserved or rediscovered fragments of labour camps or by presentation of probable former appearance of these camps (KučEROVÁ, S.R. and STYCH, P. 2015).

Various degrees of heritage protection apply, however, to material heritage only. The reason lies in legislation, since Czech laws do not provide for the protection of intangible heritage. Only a few of the most important objects are listed as protected heritage, while others are still waiting for such listing. If listed, the prestige and promotion of the objects in question may increase, thus raising potential visitor traffic in the region in terms of tourism.

However, for locals to be able to exploit present heritage potential of the area, also other conditions have to be fulfilled. Heritage based development does not come directly with heritage recognition. For example, under specific conditions, excessive preservation measures in combination with the lack of relatively wealthy and experienced private owners may result in deterioration and even destruction of protected buildings (Daugstad, K. and Grytli, E. 1999; Olwig, K.R. 2001). Thus, at the same time heritage values are recognized, proper treatment of heritage assets and technical supervision over their possible renovations should be ensured so as to prevent damage or loss of their historical, architectural or other values.

The actual enforcement of such protection is, however, another thing. The example of the town of Jáchymov shows that some $16^{\text {th }}$ century patrician houses, important evidence of the form of Renaissance architecture, are falling into disrepair and are almost ready to be demolished in spite of being listed as protected heritage, because their owners lack either funds to repair them or a simple interest in preserving them. The example of this situation reveals that heritage protection does not necessarily equal the preservation and protection of local values (HLOušEK, J. 2016). A major part of the Jáchymov heritage belongs to the category of heritage formed by change of function, i.e. secondary heritage. In the area, major objects originally connected with mining are not serving these functions anymore and mining operations with its accompanying processes (survey, excavation, transportation, etc.) diminished. Also, only a small fraction of objects was established primarily as heritage.

Secondary heritage therefore arises at a moment when a particular object loses its original function and subsequently particular values, which it is supposed to represent, are recognized. An example is the Royal Mint, which was built between 1534 and 1536 but ceased to operate in the late $17^{\text {th }}$ century. Subsequently, it was falling into disrepair until 1964, when opened as a museum, after closing of nearby uranium mines.

Thus, the mint's new function was defined and it can be regarded as heritage. Between 1964 and 1989 local heritage was managed 
by the state. Emphasis was placed on material remains of mining, and the heritage was often used to promote ideologies. After 1989, the situation changed. Private and interest sector started to be more profoundly involved in management and interpretation of local heritage.

Thus, the entire complex of the mining heritage as well as its individual parts are interpreted to the public in various forms. More sophisticated forms of interpretation are used mainly by the public sector, which administers Jáchymov's museums, and by the interest sector, which maintains and develops various traditions. Their primary goals consist in protecting the heritage as well as in passing it down to future generations, which is why they choose such forms of interpretation that may arouse public interest and motivate the biggest possible number of visitors to visit heritage places. Private entities handling the heritage, on the other hand, interpret it only by means of simple interpretation tools in the form of texts. As an example, the Svornost mine may be taken, which is owned by a private company (Léčebné lázně Jáchymov, a. s.), is used for commercial purposes and is open to the public to a very limited extent. This is happening despite the fact that this mine was founded as early as in 1518 and is therefore the oldest working mine in Czechia as well as in the whole of Europe. Moreover, it is the oldest underground uranium mine in the world (HLOUŠEK, J. 2016).

In spite of this, the interpretation of this mine by its owner consists in mere placement of information boards at the mine's premises. A similar case is the former silver mine Bratrství, which currently serves as a nuclear waste repository. These examples show that even when a particular heritage asset represents significant values, it is not guaranteed that it will be duly interpreted

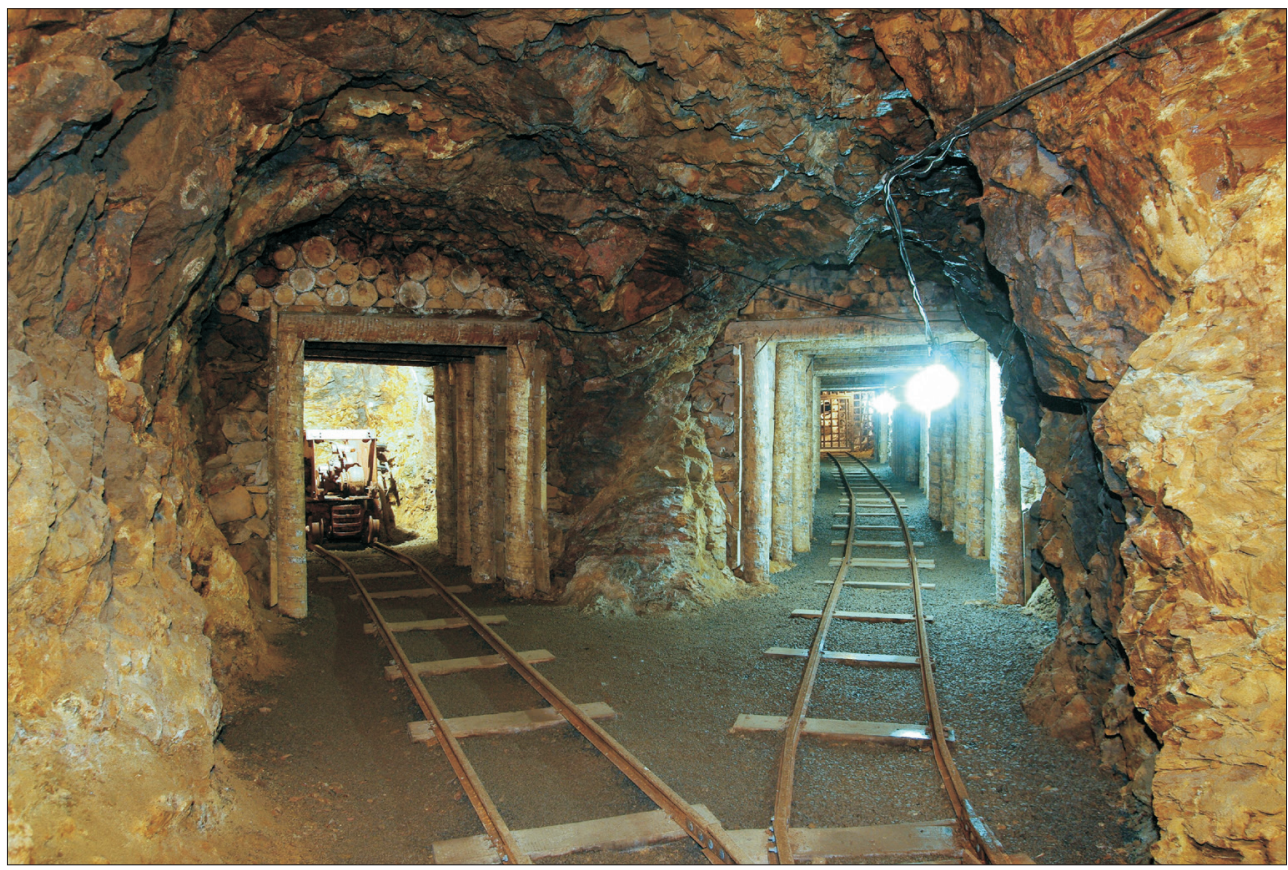

Photo 1. Gallery no. 1. Underground sightseeing gallery, open to the public. It is an example of the tangible mining heritage in the Jáchymovsko area. (Photo by JELEN, J.) 
to the public. The form and ways of interpretation therefore depend chiefly on the particular entity (owner) of the respective object. Individual elements of the Jáchymov heritage are interlinked and form a complex, which can be observed, for example, in the existence of a landscape heritage zone (KučA, K. 2015), the intermingling of local activities, the collaboration of local groups with public institutions, and the interconnection of individual parts of the heritage with nature trails (Karlovy Vary Museum, Mining Association Barbora, etc.) (Photo 1 and 2).

The exceptional diversity of minerals, the very long mining history and the huge amount of preserved heritage assets in the Jáchymovsko area, were among key arguments speaking in favour of adding this region to the nomination of the mining cultural landscape of the Ore Mountains/Erzgebirge to UNESCO's list of world cultural and natural heritage (URBAN, M. et al. 2011).

\section{Conclusions}

Heritage includes both features created primarily for the purpose of representation of certain values and meanings, and features that were created by transformation of their original function. The complex of the Jáchymovsko mining heritage is interpreted by means of a wide range of tools, with all these interpretations being aimed at passing down values and information to the public and future generations. Thus, the essence of heritage is fulfilled (HowARD, P. 2003). However, the chosen types of its interpretation depend chiefly on respective stakeholders and their primary goals.

Where the main goal is to use heritage for the purposes of tourism, education or promotion of the image of the place or miners' traditions, more sophisticated and complicated ways of interpretation are chosen. Conversely, where particular heritage object

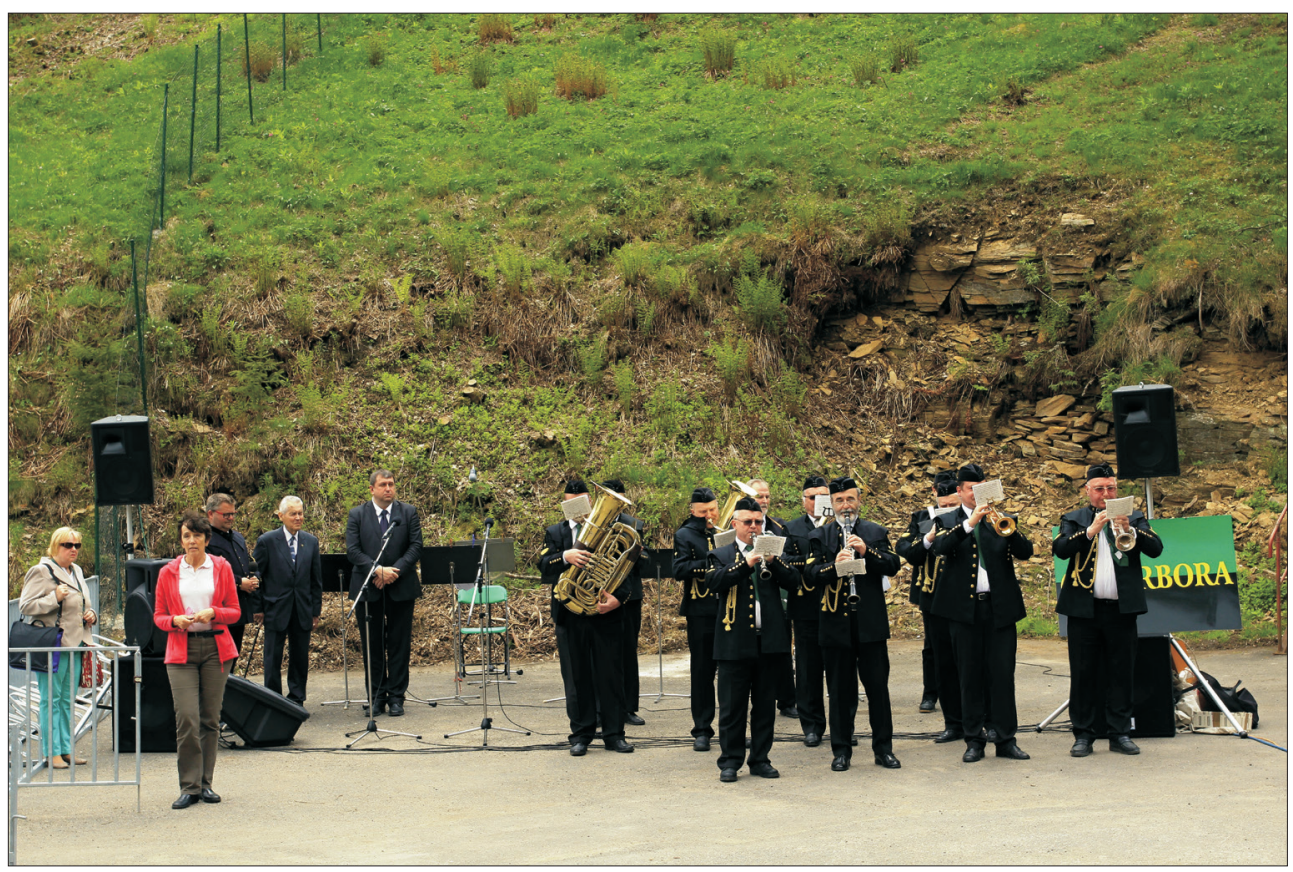

Photo 2. The Mining band Barbora. The band plays during mining festivals and other events. It is an example of the intangible mining heritage in the Jáchymovsko area. (Photo by KučErA, Z.) 
serves daily commercial or residential use, its owners neither aim nor strive to use more sophisticated tools for its interpretation. In such cases, heritage is presented in simple ways having the form of text descriptions or information boards, as a result of which its meanings are not conveyed sufficiently. This happens even in cases where the particular heritage represents exceptional architectural or historical values. The representation of local heritage is thus conducted through various forms of interpretation (AshworTH, G.J. and Tunbridge, J.E. 1996; SMith, L. 2006).

The identification and attribution of the values to particular monuments do not automatically have to result in its protection and interpretation. Despite this, it is important to pursue its preservation. To understand the origins and nature of local heritage, it is very important to focus on analysing the stakeholders dealing with the heritage, or more precisely, on the ways in which they identify, use, present and interpret the heritage to diverse subjects. The example of Jáchymov makes it evident that numerous heritage assets would deserve a more active approach to their interpretation, which would make them more attractive for visitors and locals alike and enhance the process of their preservation.

Acknowledgements: This work was supported by the Czech Science Foundation under Grant no. P410/12/G113.

\section{REFERENCES}

Ashworth, G. and Tunbridge, J.E. 1996. Dissonant Heritage: The Management of the Past as a Resource in Conflict. Chichester, Wiley.

BlažKová, T. and MatoušEK, V. 2013. Česká krajina 19. a 20. století ve světle industriální archeologie - stav bádání (Czech landscape of the $19^{\text {th }}$ and $20^{\text {th }}$ centuries in the light of industrial archaeology - state of research). In Archeologie 19. a 20. století. Ed.: VAřEKA, P., Plzeň, Západočeská univerzita v Plzni, 17-22.

BRIDGE, G. 2004. Contested terrain: Mining and the environment. Annual Review of Environment and Resources 29. 205-259.

Český národní komitét ICOMOS. http://www.icomos. cz/index.php/en/ (retrieved 29.12. 2016).

Český statistický úřad. http://czso.cz (retrieved 25.02.2017).
Cole, D. 2004. Exploring the sustainability of mining heritage tourism. Journal of Sustainable Tourism 12. (6): 480-494.

Conesa, H.M., Schulin, R. and Nowack, B. 2008. Mining landscape: A cultural tourist opportunity or an environmental problem? The study case of the Cartagena-La Unión Mining District (SE Spain). Ecological Economics 64. 690-700.

Coupland, B. and Coupland, N. 2014. The authenticating discourses of mining heritage tourism in Cornwall and Wales. Journal of Sociolinguistics 18. (4): 495-517.

Csorba, P. and Szabó, S. 2009. Degree of human transformations of landscapes: a case study from Hungary. Hungarian Geographical Bulletin 58. (2): 91-99.

Daugstad, K. and Grytli, E. 1999. How to study and manage a multi-historic landscape. Norsk Geografisk Tidsskrift 53. 85-92.

EDEnsor, T. 2005. Industrial Ruins: Space, Aesthetics and Materiality. Oxford and New York, Berg.

Fragner, B. and ZiKmund, J. 2009. Co jsme si zbořili? Bilance mizející průmyslové éry / deset let (What have we destroyed? The balance of the dying industrial age / ten years). Praha, ČVUT.

Graham, B., Ashworth, G.J. and Tunbridge, J.E. 2000. A Geography of Heritage: Power, Culture, Economy. London, Arnold.

Ham, H.S. and WeILER, B. 2012. Interpretation as the centrepiece of sustainable wildlife tourism. In Sustainable Tourism: A Global Perspective. Eds.: Harris, R., Grrifin, T. and Williams, P., New York, Routledge, 35-44.

Harvey, D.C. 2001. Heritage pasts and heritage presents: Temporality, meaning and the scope of heritage studies. International Journal of Heritage Studies 7. (4): 319-338.

Harvey, D.C. 2008. The history of heritage. In The Ashgate Research Companion to Heritage and Identity. Eds.: Graham, B. and Howard, P., Ashgate, Aldershot, 19-36.

Hewison, R. 1989. Heritage: An interpretation. In Heritage Interpretation. Ed.: Uzzell, L., London, Belhaven, 15-23.

Hloušek, J. 2016. Jáchymov, Joachimsthal. Díl I. + II. Jáchymov, Kateřina Hloušková.

Holtorf, C. 2002. The Monumental Past. Toronto, University of Toronto Press.

Hornická kapela Barbora. http://kapelabarbora.webnode.cz/ (retrieved 05.02.2017).

HowARD, P. 2003. Heritage: Management, Interpretation, Identity. London, Continuum.

Hudson, K. 1965. The Industrial Archaeology of Southern England. London, David \& Charles.

Jelen, J. and Kučera, Z. 2017. Dědictví (nejen) uranové těžby na Jáchymovsku (Heritage of [not only] uranium mining in Jáchymov area). Geografické rozhledy 26. (3): $28-30$. 
KAFKA, J. 2003. Rudné a uranové hornictví České republiky (Ore and uranium mining of the Czech Republic). Praha, DIAMO.

Karel, T. and Kratochvílová, A. eds. 2013. Proměny montánní krajiny. Historické sídelní a montánní struktury Krušnohoří (Changes of the mining landscape. Historic settlement and mining structures of the Ore Mountains). Loket, Národní památkový ústav.

Kesner, L., Moravec, I., Novotný, R. and ŠKodováParmová, D. 2008. Management kulturního cestovního ruchu (Management of cultural tourism). Praha, Cultropa.

KIss, É. 2009. Major trends in the development of industrial areas of Budapest in the early $21^{\text {st }}$ century. Hungarian Geographical Bulletin 58. (3): 163-180.

KolejKa, J. 2014. Industrial heritage - Past and present state of post-industrial landscape Kamenicko. Životné prostredie 48. (4): 227-231.

KolejKA, J. and KLIMÁNEK, M. 2012. Vymezení a typologie postindustriální krajiny Česka (Specification and typology of post-industrial landscape of the Czechia). Geografie 117. (3): 289-307.

KopačKA, L. 1996. Strukturální změny ekonomiky se zvláštním zřetelem k průmyslu (Structural changes in the economy with special focus to industry). In Geografická organizace společnosti a transformační procesy v České republice. Ed.: Hampl, M., Praha, DemoArt, 219-238.

Kratochvílová, A. 2014. Prohlašování montánních objektů za kulturní památky (Declaration of mining objects for cultural monuments). Sborník příspěvků odborného workshopu k problematice zachování, obnově a zpřístupňování důlních děl a hornické krajiny. Most, Národní památkový ústav, 63-70.

KuČa, K., Kučová, V., Salašová, A., Vorel, I., Weber, M. et al. 2015. Krajinné památkové zóny České republiky (Landscape conservation areas in the Czech Republic). Praha, Národní památkový ústav, generální ředitelství.

KučERA, Z. 2009. Krajina jako dědictví (Landscape as a heritage). In Kulturní regiony a geografie kultury. Eds.: Heřmanová, E., Сhromý, P. et al. Praha, ASPI, 156-180.

KuČERovÁ, S.R. and ŠTYCH, P. 2015. 3D vizualizace zaniklých jáchymovských lágrů (3D visualization of the defunct Jáchymov camps). Informace ČGS 32. (2): 78-80.

LEDNICKÝ, V. 2004. Využití technických památek v českém cestovním ruchu (Using of the technical monuments in the Czech tourism). Ostrava, VŠB-TU Ostrava.

LepKA, F. 2003. Český uran 1945-2002. Neznámé hospodářské a politické souvislosti (The Czech uranium 1945-2002. Unknown economic and political context). Liberec, Knihy 555.

Loures, L. 2008. Industrial heritage: The past in the future of the city. WSEAS Transactions on Environment and Development 4. (8): 687-696.
Lowenthal, D. 1985. The past is a foreign country. New York, Cambridge University Press.

Lowenthal, D. 1998. The Heritage Crusade and the Spoils of History. New York, Cambridge University Press.

Lowenthal, D. 2005. Natural and cultural heritage. International Journal of Heritage Studies 11. (1): 81-92.

Marhounová, M. 2009. Konverze průmyslových objektů jako platforma pro kulturní a umělecké využití (Conversion of industrial objects as a platform for cultural and artistic use). Diplomová práce. Brno, Filozofická fakulta Masarykovy Univerzity.

MazÁč, J. 2003. Technické kulturní památky (Technical cultural monuments). Ostrava, Vysoká škola báňská.

Muzeum Karlovy Vary - http://kvmuz.cz/o-nasmuzeum-jachymov (retrieved 01.02.2017).

Národní památkový ústav 2006. Mezinárodní dokumenty o ochraně kulturního dědictví (International documents about the protection of the cultural heritage). Praha, Národní památkový ústav ústřední pracoviště.

Nuryanti, W. 2005. The role of interpretation in ecotourism development. The Indonesian Institute of the Arts, 112-119. http://urp.fib.ugm.ac.id/images/ download/Wiendu\%20Nuryanti, \%20Book\%20 3,\%20UCRC\%202006.pdf (retrieved 04.02.2017)

Olwig, K.R. 2001. 'Time out of Mind' - 'Mind Out of Time': custom versus tradition in environmental heritage research and interpretation. International Journal of Heritage Studies 7. (4): 339-354.

Památkový katalog NPÚ - http://pamatkovykatalog. cz/ (retrieved 02.01.2017).

Pluskal, O. 1998. Poválečná historie jáchymovského uranu (Post-war history of the Jáchymov uranium). Praha, Český geologický ústav.

PTÁčEK, L. 2004. Interpretace místního dědictví-Příručka pro plánování a tvorbu prezentací místních zajímavostí (Local heritage interpretation - A guide to planning and creating presentations of local attractions). Brno, Nadace Partnerství.

RAISTRICK, A. 1972. Industrial Archaeology: An Historical Survey. London, Eyre Methuen.

Riegl, A. 2003. Moderní památková péče (Modern heritage care). Praha, Národní památkový ústav.

Seidlerová, I. and Seidler, J. 2007. Jáchymovská uranová ruda a výzkum radioaktivity na přelomu 19. a 20. století (Jáchymov uranium ore and radioactivity research at the turn of the $19^{\text {th }}$ and $20^{\text {th }}$ centuries). Společnost pro dějiny vědy a techniky. Praha, Národní technické muzeum.

Smith, L. 2006. The Uses of Heritage. London-New York, Routledge.

Společnost Hornické a historické Jáchymovsko (Mining and historical Jáchymovsko society). http://shhj. webnode.cz/o-nas/ (retrieved 05. 02.2017).

ŠTULC, J. 2004. Úspěchy a prohry památkové peče v obnovené demokracii (Successes and failures of the 
monument care in restored democracy). In Dějiny uměni v české společnosti: Ed.: BARTlová, M., Praha, Argo, 257-260.

Toмíš́кoví, M. 2013. Průmyslové dědictví a cestovní ruch (Industrial heritage and tourism). Urbanismus a územní rozvoj 14. (3): 28-32.

UNESCO World Heritage List - http://whc.unesco. org/en/list (retrieved 25.12.2016).

URBAN, M. et al. 2011. Tři studie k hornické a kulturní krajině českého Krušnohoři s výchozími body Krupka, Hora svaté Kateriny, Jáchymov. Část 3, Výchozí bod Jáchymov (Three studies about the Mining and Cultural Landscape of the Czech Ore Mountains with the starting points Krupka, Mount of St. Catherine, Jachymov. Part 3, Starting point Jachymov). Most, Oblastní muzeum v Mostě.

URRY, J. 1990. The Tourist Gaze: Leisure and Travel in Contemporary Societies. London, Sage.
VANĚČEK, V. 1933. Základy právního postavení klášterů a klášterního velkostatku ve starém českém státě: (12-15. století). Část proní. Zakladatelská práva (Foundations of the legal status of monasteries and monastery estate in the old Czech state: $\left[12^{\text {th }}-15^{\text {th }}\right.$ century]. Part one. Founding right). Praha, Bursík a Kohout. WheELER, R. 2014. Mining memories in a rural community: Landscape, temporality and place identity. Journal of Rural Studies 36. 22-32.

Zákon č. 20/1987 Sb., o státní památkové péči. Sbírka zákonů ČR. (Act No. 20/1987 Coll., On state monument care. The Collection of Laws of the Czech Republic.) https://www.zakonyprolidi.cz/cs/198720 (retrieved 05.01.2017).

Zákon č. 89/2012 Sb., občanský zákoník. Sbírka zákonů ČR (Act No. 89/2012 Coll., Civil Code. The Collection of Laws of the Czech Republic.) https://www. zakonyprolidi.cz/cs/2012-89 (retrieved 12.02.2017). 